\title{
Association of maternal serum homocysteine level with severity of preeclampsia: a case control study
}

\author{
Kanan Avinash Yelikar*, Sonali Satish Deshpande, Manisha Laxmikant Kulkarni
}

Department of Obstetrics and Gynecology, Government Medical College and Hospital, Aurangabad, Maharashtra, India

Received: 14 June 2016

Accepted: 02 July 2016

\section{*Correspondence:}

Dr. Kanan Avinash Yelikar,

E-mail: drkananyelikar2016@gmail.com

Copyright: () the author(s), publisher and licensee Medip Academy. This is an open-access article distributed under the terms of the Creative Commons Attribution Non-Commercial License, which permits unrestricted non-commercial use, distribution, and reproduction in any medium, provided the original work is properly cited.

\section{ABSTRACT}

Background: The objective of the study was to investigate plasma levels of homocysteine in women with preeclampsia and eclampsia, and to assess whether there is any association between hyperhomocysteinemia and the severity of preeclampsia.

Methods: In this case control study, 120 women were recruited in the study in which 40 cases of preeclampsia, 40 cases of eclampsia and 40 healthy normotensive women were taken as controls between the study period September 2013 to August 2015. Assessment of homocysteine level was done in cases and controls. Association was studied between maternal homocysteine level and preeclampsia and eclampsia and also with the severity of pre-eclampsia.

Results: There was a significant association between pre-eclampsia and eclampsia and maternal serum homocysteine levels (median homocysteine level $16.25 \mathrm{mo} \mu \mathrm{l} /$ lit with $\mathrm{P}$-value being less than 0.001 for preeclampsia ; median homocysteine level-31.34 $\mu \mathrm{mol} /$ lit with $\mathrm{p}$ value being less than 0.001 for eclampsia). There was also a significant association between severity of preeclampsia and maternal homocysteine level (mean serum homocysteine level in nonsevere preeclampsia $14.99 \pm 3.47 \mu \mathrm{mol} /$ lit with $\mathrm{p}$ value being 0.35 ; in severe preeclampsia $19.90 \pm 6.17 \mu \mathrm{mol} / \mathrm{lit}$ with $\mathrm{p}$ value less than 0.001 and $30.44 \pm 4.75 \mu \mathrm{mol} / \mathrm{lit}$ with $\mathrm{p}$ value less than 0.001 .

Conclusions: In the present study a positive association was found between pre-eclampsia and maternal serum homocysteine levels and it was found to be statistically significant. Also the levels were higher as the severity of preeclampsia increased.

Keywords: Eclampsia, Pre-eclampsia, Maternal serum homocysteine level

\section{INTRODUCTION}

Preeclampsia is a pregnancy related hypertensive disorder occurring usually after 20 weeks of gestation. Preeclampsia has remained a significant public health threat in both developed and developing countries contributing to maternal and perinatal morbidity and mortality globally. ${ }^{1,2}$ The problem is compounded by the continued mystery and unpredictable nature of the disease. According to National Health Survey 1998 preeclampsia was the most common medical disorder complicating pregnancy. Incidence of preeclampsia is 5 $7 \%$ of all pregnancies. ${ }^{3}$ Though the exact cause of preeclampsia is undecided; endothelial dysfunction with associated intense vasospasm has been implicated in its causation. Recently homocysteine a metabolite of essential amino acid methionine has been postulated to produce oxidative stress and endothelial dysfunction and thereby producing preeclampsia. ${ }^{4}$ The association of hyperhomocysteinemia and preeclampsia has been suggested initially by Decker et al and has not been confirmed by many authors although majority of evidence suggest a positive association.

Homocysteine is a sulfur containing amino acid primarily derived from demethylation of dietary methionine, which 
is abundant in proteins of animal origin. It is an essential amino acid required for the growth of cells and tissues in the human body. Elevated circulating homocysteine is a risk factor of endothelial dysfunction and vascular disease such as atherosclerosis and occlusive disorders. ${ }^{5}$ The vascular effects of hyperhomocysteinemia have been proposed to include endothelial cell injury and thrombus formation. $^{5}$ Levels of maternal serum homocysteine normally decreases with gestation, either due to a physiological response to the pregnancy, increase is estrogen, hemodilution from increased plasma volume or increased demand for methionine by both the mother and fetus ${ }^{6,7,8}$. Maternal hyperhomocysteinemia has been associated with a number of placenta-mediated diseases such as preeclampsia. Homocysteine may prove to be the missing link in etiology of preeclampsia. Further homocysteine levels are known to increase with increasing severity of preeclampsia. The homocysteinemediated vascular changes are similar to those associated with preeclampsia; therefore, a hypothesis has been proposed that hyperhomocysteinemia may be associated with this condition. Several studies have indicated that homocysteine concentrations are increased in women with preeclampsia (Zeeman et al) but so far there are very few reports concerning hyperhomocysteinemia in patients with eclampsia.

Importantly vitamin status, primarily of folate, vitamin B12 and B6, is a major determinant of hyperhomocysteinemia and thus aptly said "adequate intake of Folic acid and other vitamins by the pregnant woman is the future for prevention of dreadful disease like preeclampsia".

We therefore aimed this study to investigate plasma levels of homocysteine in women with preeclampsia and elcampsia, and to assess whether there is an association between hyperhomocysteinemia and the severity of preeclampsia. Estimation of homocysteine may help to predict and prevent preeclampsia and eclampsia, thus reducing the undesired outcome of pregnancy.

\section{METHODS}

A case control study was carried out at Tertiary care hospital during September 2013 to August 2015.

Study population: 120 women were recruited in the study in which 40 cases of preeclampsia, 40 cases of eclampsia and 40 were taken as controls.

Inclusion criteria: Cases: Pregnant women above the gestational age of 20 weeks which were further divided into two groups; women with preeclampsia, with eclampsia Controls: Normotensive women were included in study.

Exclusion criteria: Chronic hypertension, multiple gestation, women on antifolate drugs, abruptio placentae, chronic kidney and cardiovascular diseases
Case: Case was defined on the basis of inclusion and exclusion criteria i.e. diagnosed cases of pre-eclampsia characterized by elevation of blood pressure of more than $140 \mathrm{mmHg}$ systolic or more than $90 \mathrm{~mm}$ of $\mathrm{Hg}$ diastolic with proteinuria (more than $300 \mathrm{mg} / \mathrm{l}$ in 24 hours specimen/1+by dipstick or greater in random urine sample) after 20 weeks of gestation in previously normotensive non proteinuria pregnant women and preeclampsia complicated by convulsions (eclampsia).

Control: The control constituted of equal number of matched age, parity, socio-demographic status, gestational age; healthy normotensive pregnant women visiting the labour ward.

This study was approved by Institutional Ethical Committee. Written informed consent was obtained from all participants recruited in study after they had been made aware of purpose of study. Particulars of the women were noted such as name, age, symptoms, menstrual history for menarche, last menstrual period and past menstrual cycles, history of present pregnancy. Past obstetric history was asked for duration of marriage, infertility, gravidity and parity status, recurrent abortions, pre-eclampsia, growth restriction, low birth weight, preterm delivery, prematurity, late pregnancy losses, neonatal deaths, and mental retardation in previous pregnancy. Past medical history was asked for any associated medical disorders like diabetes, thyroid disorders, exposure to radiation or autoimmune disorders, epilepsy, consumption of antifolate drug and history of consumption of iron and folic acid during pregnancy. Significant surgical history, family history was also asked. A thorough clinical examination including height, weight, pulse, blood pressure, pedal edema, thyroid enlargement, etc. was done followed by systemic examination. In obstetrical examination gestational age, presentation and amount of liquor was noted and fetal heart sounds were auscultated with stethoscope.

All preliminary and baseline investigations like complete blood count, blood grouping and typing, urine routine and microscopy and blood sugar were done. Ultrasonography was done for fetal growth, liquor and placenta. All investigations pertaining to complications of preeclampsia like liver and kidney function tests, serum uric acid were also done.

Assessment of serum homocysteine levels of cases and controls were done for which $5 \mathrm{ml}$ venous blood sample was taken from the antecubital vein irrespective of fasting status (i) In cases, after the diagnosis of pre-eclampsia or eclampsia was made immediate after admission and before the initiation of the antihypertensive treatment and before the delivery and (ii) In controls, after admission. All the specimens were transported to the laboratory within 30 minutes of collection. Thereafter, specimens were centrifuged for 5-7 minutes at $3000 \mathrm{rpm}$. Then clear serum was transfused in a plastic vial and stored in refrigeration until analysis. Samples were stored at $2-8^{\circ} \mathrm{C}$ 
(stable upto 14 days when refrigerated). Chemilumeniscence immunoassay was used for determining total homocysteine levels in the blood.The system used was an automated, random access, direct CLIA analyzer. This diagnostic test was designed to quantitatively measure Hcy in serum or EDTA plasma. Women were also classified according to the severity of pre-eclampsia into severe and non-severe.

Normal range: 3.7 - $13.9 \mu \mathrm{mol} / \mathrm{lit}$.

Level more than $13.9 \mu \mathrm{mol} / \mathrm{lit}$ were defined as hyperhomocysteinmia.

Statistical analysis-Statistical comparison between cases and controls was done using Pearson's chi square test, Kruskal Wallis test, odd's ratio, Mann Whitney's test which ever was appropriate, p value below 0.05 was considered to be significant.

\section{RESULTS}

Table 1: Distribution of cases and controls according to age, parity and gestational age.

\begin{tabular}{|c|c|c|c|}
\hline Characteristics & Preeclampsia & Eclampsia & Controls \\
\hline $\begin{array}{l}\text { Age in years } \\
\text { (median)* }\end{array}$ & 22 & 22 & 23 \\
\hline Nulliparas (\%) & 50 & 47.5 & 67.5 \\
\hline $\begin{array}{l}\text { Gestational age } \\
\text { inweeks(median)* }\end{array}$ & 37.15 & 35.35 & 35.35 \\
\hline
\end{tabular}

*As the data was not evenly distributed median value is calculated.

The case and control group were comparable in age, parity and gestational age in weeks.

Table 2: Distribution according serum homocysteine level in preeclampsia.

\begin{tabular}{|lllll|}
\hline Outcome & \multicolumn{3}{c}{ Homocysteine $(\mu \mathrm{mol} / \mathrm{L})$} & P value \\
\cline { 2 - 4 } & Median & $\begin{array}{l}25^{\text {th }} \\
\text { percentile }\end{array}$ & $\begin{array}{l}75^{\text {th }} \\
\text { percentile }\end{array}$ & \\
\hline $\begin{array}{l}\text { Preeclampsia } \\
\text { Cases (n=40) }\end{array}$ & 16.25 & 13.82 & 21.00 & $<0.001$ \\
\hline $\begin{array}{l}\text { Controls } \\
(\mathrm{n}=40)\end{array}$ & 12.68 & 10.00 & 14.15 & (VHS) \\
\hline
\end{tabular}

Mann Whitney test; $\mathrm{p}<0.001$

Table 3: Distribution according to serum homocysteine level eclampsia.

\begin{tabular}{|lllll|}
\hline Outcome & \multicolumn{3}{c}{ Homocysteine $(\mu \mathrm{mmol} / \mathrm{L})$} & P value \\
\cline { 2 - 4 } & Median & $\begin{array}{l}25^{\text {th }} \\
\text { percentile }\end{array}$ & $\begin{array}{l}75^{\text {th }} \\
\text { percentile }\end{array}$ & \\
\hline $\begin{array}{l}\text { Preeclampsia } \\
\text { Cases (n=40) }\end{array}$ & 16.25 & 13.82 & 21.00 & $<0.001$ \\
$\begin{array}{l}\text { Controls } \\
(\mathrm{n}=40)\end{array}$ & 12.68 & 10.00 & 14.15 & \begin{tabular}{c} 
(VHS) \\
\hline
\end{tabular} \\
\hline
\end{tabular}

Mann Whitney test; $\mathrm{p}<0.001$
Median serum homocysteine level for preeclampsia study group was $16.25 \mu \mathrm{mo}$; /lit; $25^{\text {th }}$ percentile was 13.82 whereas $75^{\text {th }}$ percentile was $21 \mu \mathrm{mol} / \mathrm{lit}$. Median serum homocysteine level for control group was $12.68 \mu \mathrm{mol} / \mathrm{lit}$ and $25^{\text {th }}$ and $75^{\text {th }}$ percentile were 10 and $14.15 \mu \mathrm{mol} / \mathrm{lit}$ respectively. It was found that there was significant difference between preeclampsia group and control group with $\mathrm{p}$ value of $<0.01$ (Mann Whitney test) (Table 2).

Median serum homocysteine levels in eclampsia study group was $31.34 \mu \mathrm{mol} / \mathrm{lit}$; 25 th percentile was 28.40 and 75th percentile was $34.56 \mu \mathrm{mol} / \mathrm{lit}$. Median serum homocysteine level for control group was $12.68 \mu \mathrm{mol} / \mathrm{lit}$ and 25 th and 75 th percentile 10 and $14.15 \mu \mathrm{mol} / \mathrm{lit}$. It was found that there was highly significant difference between eclampsia group and control with $\mathrm{p}$ value of $<0.01$ (Mann Whitney test) (Table 3).

Table 4: Association of homocysteine levels with nonsevere preeclampsia, severe preeclampsia and eclampsia.

\begin{tabular}{|lll|}
\hline Group & Mean & $\mathrm{p}$-value \\
\hline $\begin{array}{l}\text { Nonsevere } \\
\text { preeclampsia }(\mathrm{n}=16)\end{array}$ & $14.99 \pm 3.47$ & 0.35 \\
\hline $\begin{array}{l}\text { Severe preeclampsia } \\
(\mathrm{n}=24)\end{array}$ & $19.90 \pm 6.17$ & $<0.001(\mathrm{VHS})$ \\
\hline Eclampsia $(\mathrm{n}=40)$ & $30.44 \pm 4.75$ & $<0.001(\mathrm{VHS})$ \\
\hline Control $(\mathrm{n}=40)$ & $12.48 \pm 2.95$ & \\
\hline Bonferroni’s test; $\mathrm{p}<0.001$ & & \\
\hline
\end{tabular}

It is seen that there is significant difference between severe preeclampsia and controls $(\mathrm{p}<0.001)$; eclampsia and controls $(\mathrm{p}<0.001)$ but there is no statistically difference between nonsevere preeclampsia and control group $(\mathrm{p}=0.35)$ (Table 4$)$.

\section{DISCUSSION}

Pre-eclampsia is a serious complication of pregnancy with unknown etiology that may occur at any stage of second or third trimester. Pre-eclampsia is a leading cause of maternal and fetal morbidity. Although, the exact cause of pre-eclampsia is still unknown, it is known that in pre-eclampsia the basic pathology is endothelial dysfunction and intense vasospasm. Recently homocysteine, a metabolite of essential amino acid methionine, has been postulated to produce oxidative stress and endothelial cell dysfunction. Elevated plasma homocysteine concentration is an independent risk factor for peripheral vascular diseases and for coronary artery diseases. Serum homocysteine may prove to be the missing link in the etiology of preeclampsia.

Laskowaka $\mathrm{M}$ et al and Ingec $\mathrm{M}$ et al observed that mean serum homocysteine level for preeclampsia and eclampsia was $10.38 \pm 3.5 \mu \mathrm{mol} / \mathrm{lit}$ and $16.7 \pm 10.1 \mu \mathrm{mol} / \mathrm{lit}$ respectively. ${ }^{9,10}$ In the present study, median maternal serum homocysteine levels for preeclampsia group, 
eclampsia group and control group were $16.25 \mu \mathrm{mol} / \mathrm{lit}$, $31.34 \mu \mathrm{mol} /$ lit and $12.68 \mu \mathrm{mol} / \mathrm{lit}$ respectively.

Ezzatalsadat Haji Seid Javadi et al reported that the mean maternal serum homocysteine levels in the third trimester of pregnancy was found to be decreased compared to non-pregnant people and serum homocysteine levels in patients with severe preeclampsia were significantly higher $(\mathrm{P}<0.001)$ but no significant difference in the mean serum homocysteine level between women with mild preeclampsia and nonpregnant women. ${ }^{11}$ They emphasized that the low concentration of homocysteine makes trivial changes in vascular endothelium. Khosrowbeygi A, Ahmadvand $\mathrm{H}$ revealed that total maternal serum homocysteine level was increased in preeclamptic women and hyperhomocystenemia was associated with severity of preeclampsia. ${ }^{12}$ Acilims YG et al showed that maternal and fetal serum homocysteine levels were found to be significantly higher in severe preeclampsia group than in mild preeclampsia and control group suggesting that elevated level of serum homocysteine might be associated with severity of preeclampsia. ${ }^{13}$ Dudani et al observed that a significant difference in homocysteine level between hypertensive pregnant women and those with mild preeclampsia. ${ }^{14}$ In different Studies, a contradictory results have been obtained about the significant increase in homocysteine in mild preeclampsia. The reason for this could be the low concentration of homocysteine slightly affects the endothelium and has a subtle role in occurrence of preeclampsia.

\section{CONCLUSION}

This study revealed a direct relationship between serum homocysteine concentrations with severe preeclampsia, eclampsia group and failed to demonstrate the same association with nonsevere preeclampsia group. This study recommends that a multicentric cohort study with large population is needed to support the hypothesis that hyperhomocysteinemia is associated with preeclampsia and it's severity. However with regards to results of present study "measurement of homocysteine" can be suggested as a prediction of preeclampsia. To enjoy the healthy period throughout the pregnancy and enjoy the safe motherhood is right of every women.

As the preeclampsia is the commonly encountered and dreadful disease of pregnancy it is important to prevent and diagnose the disease at the earliest to prevent complications and adverse outcomes of pregnancy due to this threat.

This study recommends that a multicentric study with large population is needed to support the hypothesis that hyperhomocysteinemia are associated with preeclampsia and it's severity. However with regards to results of present study "measurement of Homocysteine" can be suggested as a prediction of preeclampsia.
By using the serum homocysteine level as predictive tool, we can diagnose the preeclampsia and it's severity so we can intervene at the earliest.

Adequate supplementation of Folic acid, B12, and B6 in preconceptional period will help to prevent hyperhomocysteinemia and thus indirectly preeclampsia.

Funding: No funding sources

Conflict of interest: None declared

Ethical approval: The study was approved by the Institutional Ethics Committee

\section{REFERENCES}

1. Fernando A. Hypertensive disorders in pregnancy. In: Practical guide to high risk pregnancy and delivery. $3^{\text {rd }}$ eds. Philadelphia: Mosby; 1994:183207.

2. Report of National high blood pressure education programme working group on high blood pressure in pregnancy.

3. Gary CF, Leveno KJ, Bloom SL, Hauth JC, Gilstrap L, Wenstorm KD. Pregnancy hypertension. In: William Obstetrics, $23^{\text {rd }}$ Ed. New York: McGraw Hill; 2005:706-14

4. Ueland PM, Homocysteine species as components of plasma redox thiol status. Clin Chem. 1995;41:3402.

5. Malinow MR, Boston AG, Krauss RM, Homocysteine, diet and cardiovascular diseases: A statement for healthcare professionals from the Nutrition Committee, American Heart Association. Circulation. 1999;99:178-82.

6. Walker MC, Smith GN, Perkins SL, Keely EJ, Garner PR. Changes in homocysteine levels during normal pregnancy. Am J Obstet Gynecol. 1999;180:660-4.

7. Hogg BB, Tamura T, Johnston KE, DuBard MB, Goldenberg MA, Goldenberg RL. Second-trimester plasma homocysteine levels and pregnancy-induced hypertension, preeclampsia, and intrauterine growth restriction. Am J Obstet Gynecol. 2000;183:805-9.

8. Vollset SE, Refsum H, Irgens LM, Emblem BM, Tverdal A, Gjes-sing HK, Monsen AL, Ueland PM. Plasma total homocysteine, pregnancy complications, and adverse pregnancy outcomes: the Hordaland Homocysteine study. Am J Clin Nutr. 2000;71:962-8.

9. Laskowaka M. Analysis of the homocysteine levels in maternal serum in pregnancies complicated by severe preeclampsia. Lublin Poland;2010.

10. Ingec $M$. Elevated Plasma Homocysteine Concentrations in Severe Preclampsia and Eclampsia:Tohoku J Exp Med. 2005;206:225-31.

11. Javadi EHS. The relationship between the level of homocysteinemia in mother's serum and the intensity of preeclampsia. Life Science Journal. 2012;9(4). 
12. Khosrowbeygi A. Circulating levels of homocysteine in preclamptic women: Bangladesh Med Res Bull. 2011;106-9.

13. Acilmis YG. Homocysteine, folic acid and vitamin B12 levels in maternal and umbilical cord plasma and homocysteine levels in placenta in pregnant women with preeclampsia. J Obstet Gynecol Res. 2011;37(1):45-50.
14. Dudani AL, Khoja A, Karira KA. Assessment of Homocysteine levels in preclampdia. Med Chanel. 2006;12(2):16-8.

Cite this article as: Yelikar KA, Deshpande SS, Kulkarni ML. Association of maternal serum homocysteine level with severity of preeclampsia: a case control study. Int J Reprod Contracept Obstet Gynecol 2016;5:2713-7. 